\title{
Contents and Utilization of Palm Oill Fruit Waste
}

\author{
Melvia Sundalian ${ }^{1, *}$, Dhia Larissa ${ }^{1}$, Oo Suprijana ${ }^{1}$ \\ 1 Sekolah Tinggi Farmasi Indonesia, Bandung, Indonesia; melviasundalian@stfi.ac.id (M.S.), dhialarissa@gmail.com \\ (D.L.), oosuprijana@stfi.ac.id (O.S.); \\ * Correspondence: melviasundalian@stfi.ac.id;
}

Scopus Author ID 57212552414

Received: 3.09.2020; Revised: 9.10.2020; Accepted: 10.10.2020; Published: 13.10.2020

\begin{abstract}
Oil palm (Elaeis guineensis Jacq) is a part of the family of Arecaceae, which originated from West Africa. Oil palm can be grown in the tropics of Asia, Africa, and Central and South America. Palm oil produces two types of oil: Crude Palm Oil (CPO) and Palm Kernel Oil (PKO). Indonesia's CPO production reaches 49 million tonnes in 2020. This production produces around 35-40\% of waste. Fresh Fruit Bunch (FFB) is extracted into Crude Palm Oil (CPO) and Palm Kernel Oil (PKO), which produce waste such as Palm Oil Mill Effluent (POME), Empty Fruit Bunch (EFB), Mesocarp Fiber (MF), Palm Kernel Shell (PKS) and Palm Kernel Meal (PKM). Palm oil production increases every year, which causes the waste from the industry to increase too. Palm oil waste still has chemical content that is good enough to be utilized. The study was conducted online at Google Scholar and PubMed by reviewing literature from domestic and international journals and research reports. The results showed that each waste contains different content, including carbohydrates, protein, fat, lignin, cellulose, mannose, and others. This waste has also been used in various fields. This waste has also been used for livestock, fuel, and raw materials.
\end{abstract}

Keywords: palm oil waste; contents; utilization.

(C) 2020 by the authors. This article is an open-access article distributed under the terms and conditions of the Creative Commons Attribution (CC BY) license (https://creativecommons.org/licenses/by/4.0/).

\section{Introduction}

Oil palm (Elaeis guineensis Jacq) is a part of the family of Arecaceae, which originated from West Africa. Oil palm can be grown in the tropics of Asia, Africa, and Central and South America. The development of oil palm plantations in Asia started in the Botanic Gardens in Bogor, Indonesia, where the oil palm seed was introduced from Mauritius and Amsterdam [1]. Data from the Directorate General of Plantation, Ministry of Agriculture of Indonesia, from 2014 to 2018, the total area of oil palm increased by 3,571,549 hectares [2]. Indonesia has become the world's leading producer of crude palm oil with the production of 23.9 million tonnes in 2011; Indonesia contributed $49.7 \%$ of world production, followed by Malaysia (37.8\%), Thailand (3.2\%), Nigeria (1.8\%), and Colombia (1.7\%) [3].

Palm oil produces two types of oil: crude palm oil (CPO) and palm kernel oil (PKO) [4]. Palm oil is one of the most consumed oils in the world. This cheap and easy to produce oil is used for a wide variety of foods, cosmetics, cleaning agents, and others. Malaysia and Indonesia are the largest producers of palm kernel oil, while the Philippines and Indonesia are the largest producers of crude palm oil (CPO) [5]. The potential for oil palm in Indonesia is very large; the palm oil industry has grown to 608 industries in 22 provinces. Data from the Directorate General of Plantation, Ministry of Agriculture of Indonesia 2020, show that Indonesia's CPO production reached 42.9 million tons in 2018 and is expected to reach 49 
million tons by 2020 [2]. On the other side, this product will produce around $35-40 \%$ of waste, so that is estimated there will be 19.6 million tons of waste by 2020. Palm oil production increases every year, which causes the waste from the industry to increase too [4]. In fact, palm oil waste still has chemical content that is good enough to be utilized.

There are two processes for extracting palm oil from Fresh Fruit Bunch: chemical extraction using solvents and physical extraction with an emphasis on oil palm. Extraction with emphasis is an extraction that is widely used because of the easy process and cheap. However, in processing oil palm, it will leave a residue known as palm oil waste. Waste from oil palm processing has the potential to be utilized if managed properly. There are two types of palm oil production waste, liquid waste such as Palm Oil Mill Effluent (POME), and solid waste such as Empty Fruit Bunch (EFB), Palm Kernel Meal / Palm Kernel Cake (PKM), Mesocarp Fiber (MF), and Palm Kernel Shell (PKS) [4], [6], [7].

The composition of the waste varies depending on the season and the quality of the raw materials. POME, with its organic content, is commonly used for biogas production [8]. EFB contains nanocellulose, which are useful in the pharmaceutical and food fields [9]. EFB can also produce activated carbon and is used as an adsorbent, such as MF and PKS [10]-[14]. PKC contains D-mannose, which has a wide application in the pharmaceutical industry, in the food and feed industry [15] and has an important role in human metabolism. D-mannose has been shown to prevent recurrent urinary tract infections [16]. There have been several studies conducted to analyze the chemical content of PKC. PKC from the screw extraction process or pressing the palm kernel contains carbohydrates, protein, crude fiber, and oil, as well as crude fat. PKC can be explored as a potential source of important components for human nutrition [5], [17].

From the background presented, seeing the great potential of palm oil waste as a source of nutrition for health and a source of raw materials in the pharmaceutical sector, this article aims to gather information regarding the content of some oil palm waste and its benefits so that it can be used for the future development of palm oil waste.

\section{Materials and Methods}

Research Conducted online at Google Scholar. The research was conducted in Indonesian and English. Literature reviews were obtained from domestic and international journals and research reports in March-August 2020. The number of literature reviewed was 65 journals.

\section{Results and Discussion}

Oil palm (Elaeis) is an industrial plant as a raw material for producing oil belonging to the family Arecaceae, which consists of two species, one of them is African Palm Oil (Elaeis guineensis Jacq). Palm oil produces two types of oil: crude palm oil (CPO) and palm kernel oil (PKO) [4]. Palm oil is one of the most consumed oils in the world. This cheap and easy to produce oil is used for a wide variety of foods, cosmetics, cleaning agents, and others [5]. Palm oil has the same amount of saturated and unsaturated fatty acids. Palmitic acid is saturated fat, while oleic acid is an unsaturated fatty acid. With around 500-700 ppm of carotenoids, palm oil is the richest source of $\beta$-carotene. This oil is also very rich in vitamin E, especially tocotrienols and tocopherols. Carotenoids and vitamin E act synergistically as a powerful natural antioxidant [18]. 
There are two processes for extracting palm oil from the Fresh Fruit Bunch (FFB), namely, chemical extraction using solvents and physical extraction with an emphasis on oil palm. Extraction with emphasis is an extraction that is widely used because of the easy process and cheap. However, in processing, palm oil will leave a residue that is commonly known as palm oil [4]. The flow chart for processing FFB into CPO and PKO is depicted in Scheme 1.

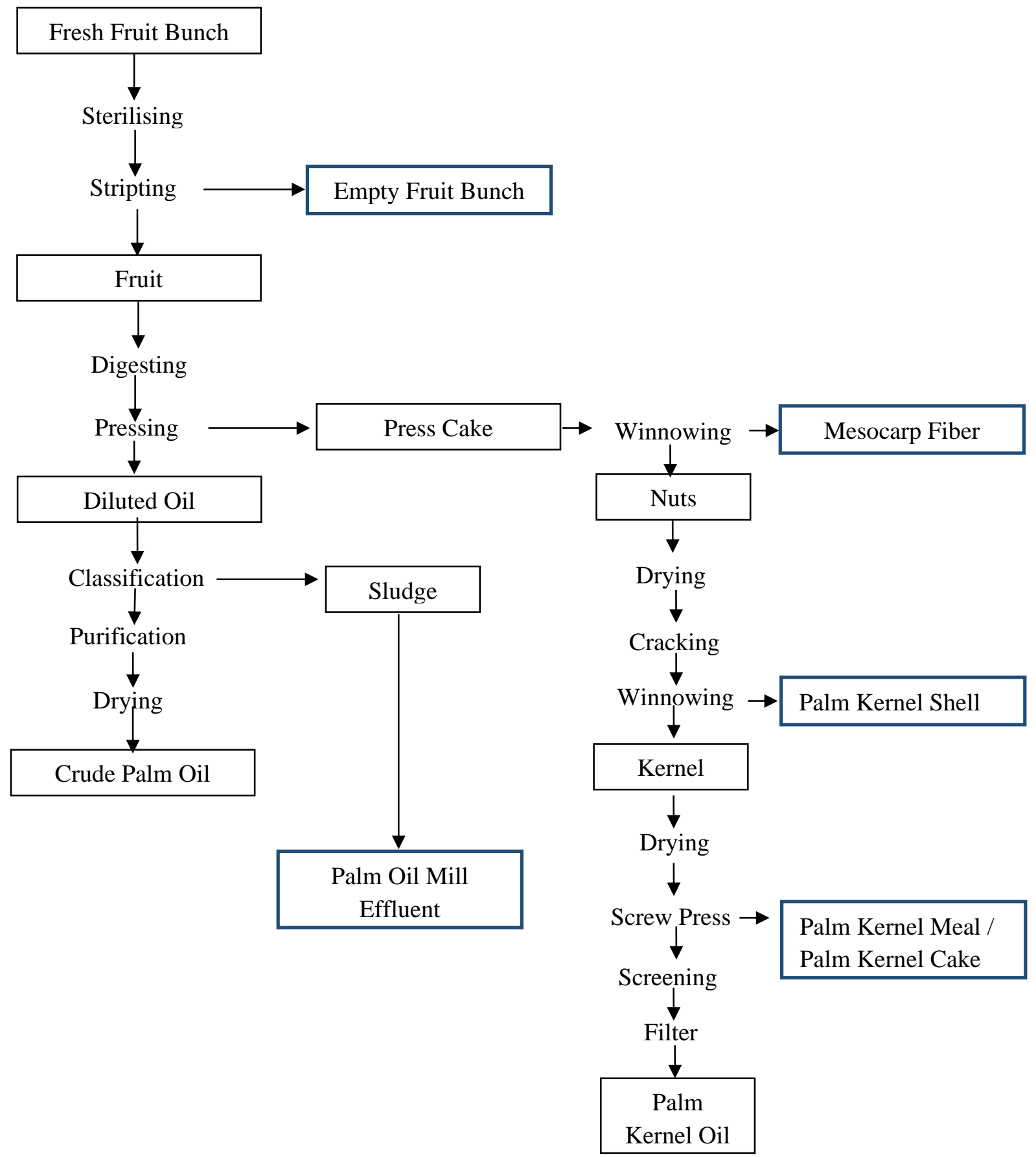

Scheme 1. Flow Chart of FFB processing into CPO and PKO [4], [21], [23], [24].

\subsection{Contents of palm oil waste}

\subsubsection{Palm oil mill effluent (POME)}

POME is liquid waste from the palm oil production process. Typically, POME is produced from plant operations at temperatures between $80^{\circ} \mathrm{C}$ and $90^{\circ} \mathrm{C}$. The characteristics of POME depend on the quality of the raw material and the oil production process in palm oil 
mills. POME is acidic ( $\mathrm{pH} 4-5)$. POME is thick brown in color, which contains a high concentration of organic compounds [19]-[21]. POME accounts for the largest portion of all waste generated in the FFB extraction process [22]. POME has high carbon and hydrogen content, as well as low nitrogen and sulfur content [20]. Heavy metals, such as $\mathrm{Pb}$, can also be in POME, but their concentrations are below sublethal levels $(>17.5 \mu \mathrm{g} / \mathrm{g})$. $\mathrm{Pb}$ is commonly found in POME as contamination from plastics, metal pipes, and tanks, where $\mathrm{Pb}$ is widely used in paints and glass materials [21].

The high concentration of carbohydrates, protein, lipids, and minerals are present in POME. It makes a good raw material for biological conversion through various processes biotechnological. Table 1 shows the direct composition (\%) of the main constituents of POME.

Table 1. Chemical Component of Palm Oil Mill Effluent.

\begin{tabular}{l|l} 
Component & Range \\
\hline Moisture & 6.99 \\
\hline Crude Protein & 12.75 \\
\hline Crude Lipid & 10.21 \\
\hline Ash & 14.88 \\
\hline Carbohydrate & 29.55 \\
\hline Total Carotenoid & 0.019 \\
& {$[25]$}
\end{tabular}

POME contains carotenoid, which is isolated by column chromatography method with n-hexane and petroleum ether solvents $[19,26]$. However, n-hexane is a better solvent than petroleum ether in pulling compounds from POME. The carotenoid concentration obtained from POME is from 390-1450 ppm. The main component of POME is similar to CPO, which contains $\alpha$-carotene and $\beta$-carotene. The percentage of $\beta$-carotene was higher than $\alpha$-carotene, with a ratio of 7: 3 of POME [26]. $\alpha$-carotene and $\beta$-carotene function as antioxidants and antiinflammatory properties $[27,28]$. Carotene intake can help rejuvenate the body by promoting the growth of healthy body cells and inhibiting the growth of unhealthy cells. This carotene contributes to preventing degenerative diseases such as cardiovascular disease, diabetes, and some types of cancer [27].

\subsubsection{Empty fruit bunch (EFB).}

In the extraction process of Crude Palm Oil (CPO) from the Fresh Fruit Bunch (FFB), it produces not only POME, but also Empty Fruit Bunch (EFB). As much as $25-26 \%$ of total CPO production is EFB [29]. However, only about $10 \%$ is used for fuel and compost; the rest is still waste [9]. EFB is composed of several important substances that can be used as other materials of economic value. Its main components include cellulose, lignin, holocellulose, hemicellulose, water, and other substances [29]. The chemical components of EFB can be seen in Table 2.

Cellulose and Nanocellulose were successfully extracted from EFB [9, 31]. Nanocellulose is produced by hydrolyzing EFB with sulfuric acid. The hydrolysis time is an important factor in changing the properties of nanocellulose. The best time to isolate nanocellulose from EFB using sulfuric acid hydrolysis is 60 minutes [31]. Cellulose and nanocellulose are classified as safe for processing and consumption. Cellulose and some of its derivatives are FDA approved as additives in food and medicinal products [32]. 
Table 2. Chemical component of Empty Fruit Bunch.

\begin{tabular}{l|l} 
Komponen & Kadar $(\boldsymbol{\%})$ \\
\hline Moisture & $2.44-15.01$ \\
\hline Lignin & $23.9-25.83$ \\
\hline Holoselulosa & 56.49 \\
\hline Selulosa & 33.25 \\
\hline Hemiselulosa & 23.24 \\
\hline Ash & $4.48-5.26$ \\
\hline Karbon Tetap & $0.98-18.67$ \\
\hline Volatile Matter & $73.63-79.58[6],[11],[29]$ \\
\hline Glucan & $31.4[30]$ \\
\hline Xylan & $18.6[30]$ \\
\hline Arabinan & $2.7[30]$
\end{tabular}

EFB contains carbohydrates that consist of several components, as in table 2, one of which is xylan [30]. Xylan is a pentose or xylose polymer with B-1,4 bonds whose monomer numbers range from 150-200 units. Xylan has many benefits as an industrial raw material, including as a thicking agent (thickener) and as a raw material for making films. In addition, xylan is also used as an endo-B-1,4-D-xylanase substrate. Endo-B-1,4-D-xylanase hydrolyzes xylan to xylooligosaccharides and xylose [6]. Xylooligosaccharides are very beneficial for health, namely stimulating the growth of bifidobacteria in the human gut so that xylooligosaccharides are considered prebiotics [33].

Palm oil waste as a biomass resource in Indonesia has not been fully utilized. One of the products that can be made from oil palm biomass as activated carbon [34]. EFB is a potential precursor for activated carbon production. Several studies have shown that EFB can be used as an adsorbent to remove heavy metals such as $\mathrm{Hg}$ (III), $\mathrm{Pb}$ (III), and $\mathrm{Cu}$ (III). Characterization studies indicate that the use of activated carbon-zinc chloride has a yield $(37.9 \%)$, carbon content $(87.15 \%)$, and surface area $\left(86.62 \mathrm{~m}^{2} / \mathrm{g}\right)$ was higher than activated carbon without chemical activation [12]. The surface area of activated carbon using the BET gain is as high as $720 \mathrm{~m}^{2} / \mathrm{g}$. This value is still included in the commercial activated carbon range $\left(500-1500 \mathrm{~m}^{2} / \mathrm{g}\right)$ [11]. Meanwhile, the surface area of activated carbon activated by $\mathrm{KOH}$ was $807.54 \mathrm{~m}^{2} / \mathrm{g}$ [10]

\subsubsection{Mesocarp fiber (MF).}

Mesocarp fiber has a hard and strong texture [35]. As much as 13\% of total coconut oil production is a by-product, namely Palm Fiber [36]. Chemical components of Mesocarp Fiber are in Table 3.

Table 3. Chemical component Mesocarp Fiber.

\begin{tabular}{l|l} 
Component & Range \\
\hline Cellulose & $42.7-65$ \\
\hline Lignin & $13.2-25.31$ \\
\hline Hemicellulose & $17.1-33.5$ \\
\hline Holocellulose & $68.3-86.3$ \\
\hline Ash Content & $1.3-7.90[6],[35]$ \\
\hline Moisture & $11.10[6]$ \\
\hline Pentosan & $17.8-20.3$ \\
\hline Arabinose & 2.5 \\
\hline Xylose & 33.1 \\
\hline Mannose & 1.3 \\
\hline Galactose & 1.0 \\
\hline Glucose & $66.4[35]$
\end{tabular}


Mesocarp fiber is rich in lignocellulose. There is potential for the production of nanocellulose from MF for various applications, especially for nanocomposite materials as reinforcing materials for the automotive industry, especially for interior applications, construction, electronics, cosmetics, packaging, and also for biomedical purposes [35].

3.1.4. Palm kernel shell (PKS).

Palm Kernel Shell is one of the wastes from palm oil production that comes from separating Nuts from Kernel [36]. PKS usually accounts for 7\% of the total palm oil production [36]. Palm shells are used to prepare activated carbon using potassium carbonate $\left(\mathrm{K}_{2} \mathrm{CO}_{3}\right)$ as an activating agent [14]. The components of the Palm Kernel Shell can be seen in Table 4.

Table 4. Chemical component of Palm Kernel Shell.

\begin{tabular}{l|l} 
Component & Range \\
\hline Cellulose & 29.70 \\
\hline Lignin & 53.40 \\
\hline Holocellulose & $47.40[37]$ \\
\hline Ash Content & $1.10-3.24$ \\
\hline Moisture & $7,96-10,23$ \\
\hline Vollatile & $0.10-85.11$ \\
\hline Carbon & $1.42-18.70[6],[37]$
\end{tabular}

\subsubsection{Palm kernel meal (PKM).}

PKO is extracted from the kernel mechanically through pressing or solvent extraction. However, due to difficult solvent recovery and safety concerns, solvent extraction is rarely used. Mechanical extraction is more commonly used because it is relatively easy and cheap [4]. From the mechanical extraction method, the results of the comparison of the proximate analysis of the kernel before extraction and the palm kernel cake, the waste from the extracted kernels are in table 5. Several studies of several beneficial wastes are shown in table 6.

Table 5. Comparison of Proximate Analysis of Kernel and Palm Kernel Meal.

\begin{tabular}{l|c|c} 
& Kernel & Meal \\
\hline Oil content & 49 & 7.9 \\
\hline Protein & 8.3 & 14.8 \\
\hline Crude Fiber & 8.1 & 16.7 \\
\hline Moisture & 6.5 & 6.4 \\
\hline Ash & 2.0 & 3.9 \\
\hline Carbohydrate & 26.1 & $50.3[5]$
\end{tabular}

Table 6. Chemical component of Palm Kernel Meal.

\begin{tabular}{l|l} 
Component & Range \\
\hline Carbohydrate & $50.3-50.4$ \\
\hline Protein & $14.8-19[5],[17],[36]$ \\
\hline Crude Fiber & $11.5-16.7$ \\
\hline Oil Content & $5.5-7.9$ \\
\hline Moisture & $6.4-8.9$ \\
\hline Ash & $3.9-6.1[5],[17]$
\end{tabular}

Along with the increase in palm kernel oil production, there is also an increase in the amount of PKM waste produced. The proportion of PKM is $45-46 \%$ of the palm kernel [38]. PKM has the potential to be reused because it contains protein between $14.19 \%-21.66 \%$, fat 9.5\% -10.5\% and crude Fiber 12.63\% [38]. Several technologies can be used to increase the value of PKM, namely chemically with immersion technology in acids or alkalis $[1,38]$. Through chemical engineering, crude fibers from PKM materials can be derived by immersion with acetic acid and formic acid or alkalis (ammonium hydroxide) [1]. The decrease in fiber 
content can be done by immersion in alkaline, because the absorption of alkali into the cell wall of the material then breaks the ester bonds in the chains of lignin, hemicellulose, and cellulose, which causes the cell wall structure to be simple [38]. PKM processing can also be done physically with filtering technology. Filtering is a simple way that can reduce crude fiber in PKM [39].

PKM is rich in nonstarch polysaccharides with the main structure galactomannan, glucomannan, and manan with a manan content of about $35.2 \%$. Manan is a polymer of Dmannose with $\beta 1,4$ and D-galactose chains, which are difficult to degrade, but when degraded, it will become mannose compounds [38]. The PKM extraction process can be carried out using PKM that has been filtered by a smaller size of $850 \mathrm{um}$. The reduction in size, followed by hot water extraction, could increase the total amount of mannan extracted to $37 \%$ of the total CCP. The utilization of acetic acid shows that the total amount that can be extracted is relatively decreasing. This suggests that the use of acids under high-temperature conditions can damage the extracted sugar components [40].

Another content of palm oil cake is D-mannose. D-mannose is a hexose which has a wide application in the pharmaceutical industry, in the food and feed industry [15] and has an important role in human metabolism, especially in the glycosylation of certain proteins. Dmannose has been shown to prevent recurrent urinary tract infections [16]. PKM also showed the highest total phenolic content $(5.35 \mathrm{mg} / \mathrm{g}$ ) compared to other wastes. Pyrogallol, 4hydroxybenzoic acid, gallic acid, and ferulic acid are the main compounds found in palm kernel cake extract [41].

\subsection{Utilization of palm oil waste.}

Palm oil production waste will continue to increase in line with the increase in world palm oil production. Therefore, the waste must be used according to its content. Several studies of several beneficial wastes are shown in table 7 .

Table 7. Utilization of Palm Oil Waste.

\begin{tabular}{l|l} 
Materials & Benefits \\
\hline Palm Oil Mill Effluent & Alternative biomass fuels [8] \\
\hline & Isolation or recovery of residual carotenes [19], [25], [26] \\
\hline Empty Fruit Bunch & Substrate for bioplastic production [25] \\
\hline & Hydrogel superabsorbent of cellulose EFB [42] \\
\hline & Hydrogel of EFB nanocellulose [43] \\
& $\begin{array}{l}\text { Nanocellulose EFB by hydrolysis of sulfuric acid, can adsorb selective metals such as Pb } \\
{[44]}\end{array}$ \\
\hline Mesocarp Fiber & Producing paper and paper powder [45] \\
\hline & Animal feed [46] \\
\hline & Alternative carriers in emulsion preparations [47] \\
\hline Palm Kernel Shell & Isolated Fiber oil from Mesocarp Fiber [48] \\
\hline & Metal adsorbent [49] \\
\hline Palm Kernel Meal & Pyroligneous acid (PA) is used as an antioxidant, antibacterial, antifungal agent, and an \\
& alternative source for the production of anti-inflammatory drugs [50] \\
\hline & Palm Kernel Meal High nutritious animal feed [36], [39] \\
\hline & D-mannose isolation [15]
\end{tabular}

\subsubsection{Palm oil mill effluent.}

Palm oil waste is produced in large quantities in many developing countries. Its use is still limited; basically, it is used as food for animals or just as a landfill. However, they can serve as potential resources for use in several bioconversion processes to produce valuable 
products. Efforts have been made to use POME in the production of value-added products; this helps in solving the pollution problems that may be caused by its disposal.

POME produced from the palm oil mill industry is considered as biomass waste, which can be fully utilized as a renewable energy source. This residue is converted into solid biomass fuel. The experimental results show that POME is feasible as an alternative biomass fuel [8], [20]. POME is also often used as a source of carotenes. This is because the POME waste still contains carotenes from the extracted coconut oil. The remaining carotenes and oil can be isolated or recovered from POME [19], [25], [26].

POME is also useful in the production of fertilizers [51], citric acid, bioethanol, biohydrogen, bioplastics, hydrolytic enzymes [25]. The high organic content of POME makes it a good substrate for bioplastic production. A two-stage process has been developed for the production of Polyhydroxyalkanoates (PHA) using POME. The initial stage involved the production of organic acids (acetic and propionic acids) by anaerobic treatment of POME, followed by the conversion of the resulting organic acids to PHA using the phototrophic bacteria, Rhodobacter sphaeroides (IF0 12203). POME used as a cheap carbon source to produce PHA can lead to some significant economic benefits [25].

\subsubsection{Empty fruit bunch.}

EFB can be used as a hydrogel superabsorbent. The superabsorbent hydrogel is made from a mixture of EFB cellulose and carboxymethylcellulose (Na CMC). The hydrogel is a polymer gel obtained from synthetics and/or natural polymers that can be produced from cellulose. This material can absorb and hold a lot of water. To increase the swelling ability of the cellulose hydrogel, a cellulose derivative such as sodium carboxymethyl cellulose (NaCMC) can be added [42]. The hydrogel can also be made with Nanocellulose from EFB [43]

EFB-based nanocellulose (NC) was successfully produced as a super-adsorbent for water remediation by hydrolysis of sulfuric acid (NCS) and phosphate (NCP) and functioned with carbon (AC). The formation of sulfonic groups on the NCS surface can achieve a higher remediation ability than EFB-NCP. In a very short time, $2 \mathrm{wt} \%$ of the formulated superadsorbent EFB-NCS demonstrated selective and excellent metal adsorption ability against $\mathrm{Pb}$ [44]. Microcrystalline cellulose silylation (MCC) was isolated from EFB using aminosilane compounds that were synthesized by aminolysis of 3-glycidoxypropyltrimethoxysilane (GPTMS) with ethylenediamine (EDA) [52].

EFB can be used for the production of lignocellulosic bioethanol. To increase the productivity of ethanol with EFB with high lignin content, biomass was prepared by alkalinethermal pre-treatment (sodium hydroxide, $121^{\circ} \mathrm{C}, 60$ minutes) [53], [54].

\subsubsection{Mesocarp fiber.}

Mesocarp Fiber is a by-product of palm oil production. A number of approaches to process a large number of palm oil mill by-products into value-added products have been implemented. Mesocarp fiber can be utilized to produce paper and paper powder [45], animal feed [46], and as an alternative carrier in emulsion preparations [47].

Fiber oil is extracted from Mesocarp Fiber using supercritical carbon dioxide and solvents [48]. The recovery rate and the fatty acid composition of the fiber oil were compared between three different extraction methods, namely Soxhlet extraction, reflux, and cold 
methods. However, the ones that produced the highest yield were the cold method, then reflux, and the last one was soxhlet [55]. Fiber oil-based emulsion has good stability, no significant separation of oil and water phases. Therefore, fiber oil is good to be used as an alternative carrier oil in treatment product formulations [47].

\subsubsection{Palm kernel shell.}

Heavy metal contamination in water causes adverse effects on human health. Millions of tonnes of PKS are produced as waste from oil palm plantations every year. PKS is used as an effective adsorbent to remove heavy metals, namely; $\mathrm{Cr}^{6+}, \mathrm{Pb}^{2+}, \mathrm{Cd}^{2+}$ and $\mathrm{Zn}^{2+}$ from water. This PKS is also used as an adsorbent without pre-treatment with acid/base, just used with water and after drying and grinding, it is immediately applied for adsorption of metal ions [49].

PKS is also used to prepare activated carbon, which is tested to remove dyes from water. The adsorbent was prepared by 1 hour of PKS impregnation with $\mathrm{ZnCl} 2$ as the activating agent (PKS: $\mathrm{ZnCl}_{2}$ mass ratio 1: 1 and 2: 1), followed by carbonization in an autogenous atmosphere at $500^{\circ} \mathrm{C}$ and $550^{\circ} \mathrm{C}$ for 1 hour [56].

Pyroligneous acid (PA) obtained from the slow pyrolysis of palm kernel shells (PKS) has a high total phenolic content and exhibits various biological activities, including antioxidant, antibacterial, and antifungal. PA obtained by slow pyrolysis method and fractionated using column chromatography. PA from PKS has the potential to be used as an alternative to antioxidant and anti-inflammatory agents that are biodegradable, cheaper, and safer for the environment. Chemical tests and molecular docking studies add to the pharmacological justification for using MCC as an alternative source for the production of antiinflammatory drugs. Nevertheless, more research needs to be done before commercialization efforts [50], [57].

\subsubsection{Palm kernel meal.}

The most widely used PKM is as animal feed. PKM is used to feed livestock because of its nutritional content [36]. To increase the nutritional value of palm kernel cake, it can be done by reducing the PKM shell or adding enzymes. The reduction of PKM shells is quite effective with the filtering technique with a $2 \mathrm{~mm}$ diameter filter. This process can reduce the shell content in PKM by up to 50\%. The addition of enzymes increases the digestibility of nutrients (dry matter, metabolic energy, and protein) PKM. The best increase in nutrient digestibility was obtained from the addition of the enzyme Balitnak (BS4) production at a dose of $20 \mathrm{ml} / \mathrm{kg}$ of palm oil cake. This increase in digestibility was as effective as the addition of commercial (multi) enzymes at a dose of $2 \mathrm{~g} / \mathrm{kg}$ of palm kernel meal. Therefore, the filtering process followed by the addition of BS4 enzymes or commercial multi-enzymes to PKM can increase its content [39].

PKM contains high carbohydrates. D-mannose was isolated from PKM. PKM is catalytically hydrolyzed with sulfuric acid at $100^{\circ} \mathrm{C}$ and then fermented by the mannandegrading enzyme. The solution after fermentation undergoes filtration in a silica gel column, desalination by ion-exchange resin, and crystallization in ethanol to give pure D-mannose in a total yield of $48.4 \%$. D-Mannose is a hexose that has wide applications in the pharmaceutical industry, in the food and feed industry, and in biological research [15].

D-mannose is used as an inexpensive starting material for the synthesis of immunostimulating agents [58], antitumor agents [59], vitamin [60], and d-mannitol [61]. 
Currently, the biotransformation of mannitol from Indonesia, d-mannose, is a new production trend for mannitol. The reduction of d-mannose with sodium borohydride or electrolysis leads to a high d-mannitol yield of more than 31\% [62]. D-Mannitol is used in the synthesis of drugs such as oseltamivir phosphate [63] and newer drugs against AIDS [64].

PKM has similar content to aloe vera (Aloe Vera), which is good for health and beauty, and its function is closely correlated with the presence of mannose-rich polysaccharides [65]. Likewise, for $d$-glucose, $d$-fructose, $d$-ribose, and d-xylose, $d$-mannose is a moisturizing addition agent that is widely used in skincare products. d-mannose units are linked to each other by $\beta$-glycosidic bonds (1-4). d-Mannose exhibits outstanding moisturizing and tasting abilities, and leaves skin less tight, less dry, and more moisturized [64].

\section{Conclusions}

$\mathrm{CPO}$ and PKO production processes will produce by-products in the form of waste originating from the Fresh Fruit Bunch. These wastes include POME, EFB, MF, PKS, and PKM. The waste contains different content, including carbohydrates, protein, fat, lignin, cellulose, and mannose. This waste has also been used in various fields. This waste has also been used for livestock, fuel, and raw materials.

\section{Funding}

This research received no external funding.

\section{Acknowledgments}

This research has no acknowledgment.

\section{Conflicts of Interest}

The authors declare no conflict of interest.

\section{References}

1. Sharmila, A.; Alimon, A.R.; Azhar, K.; Noor, H.M.; Samsudin, A.A. Improving Nutritional Values of Palm Kernel Cake (PKC) as Poultry Feeds: A Review. Malaysian Society of Animal Production 2014, 17, 1-18.

2. Ghartina, D.; Sukriya, R.L.L. Tree Crop Estate Statistics of Indonesia 2018-2020. Directorate General of Estate Crops Ministry of Agriculture: Jakarta, 2019; pp.9-14.

3. Baudion, A.; Bosc, P.M.; Bessou, C.; Levang, P. Review of the diversity of palm oil production systems in Indonesia: Case study of two provinces: Riau and Jambi. Center for International Forestry Research 2017, https://doi.org/10.17528/cifor/006462.

4. Hambali, E.; Rivai, M. The Potential of Palm Oil Waste Biomass in Indonesia in 2020 and 2030. In: Proceedings of IOP Conference Series: Earth and Environmental Science, Bogor, Indonesia. Volume 65, 2017; https://dx.doi.org/10.1088/1755-1315/65/1/012050.

5. Ibrahim, N.A. Characteristics of Malaysian Palm Kernel and Its Product. Journal of Oil Palm Research 2013, 25, 245-252.

6. Onochie, U.P.; Obanor, A.I.; Aliu, S.A.; Igbodaro, O.O. Proximate and Ultimate Analysis of Fuel Pellets From Oil Palm Residues. Nigerian Journal of Technology 2017, 36, 987-990.

7. Abdullah, N.; Sulaiman, F. The Oil Palm Wastes in Malaysia. Biomass Now - Sustainable Growth and Use 2013, 3, http://dx.doi.org/10.5772/55302.

8. Ji, C.M.; Eong, P.P.; Tey, B.T.; Seng, C.E.; Ling, C.K. Biogas from palm oil mill effluent (POME): Opportunities and challenges from Malaysia's perspective. Renewable and Sustainable Energy Review 2013, 26, 717-726, https://doi.org/10.1016/j.rser.2013.06.008.

9. Lani, N.S.; Ngadi, N.; Johari, A.; Jusoh, M. Isolation, characterization, and application of nanocellulose from oil palm empty fruit bunch Fiber as nanocomposites. Journal of Nanomaterials 2014, 2014, https://doi.org/10.1155/2014/702538. 
10. Foo, K.Y.; Hameed, B.H. Preparation of oil palm (Elaeis) empty fruit bunch activated carbon by microwaveassisted KOH activation for the adsorption of methylene blue. Desalination 2011, 275, 302-305, https://doi.org/10.1016/j.desal.2011.03.024.

11. Hidayu, A.R.; Mohamad, N.F.; Matali, S.; Sharifah, A.S.A.K. Characterization of activated carbon prepared from oil palm empty fruit bunch using BET and FT-IR techniques. Procedia Engineering 2013, 68, 379384, https://doi.org/10.1016/j.proeng.2013.12.195.

12. Wirasnita, R.; Hadibarata, T.; Yusoff, A.R.M.; Lazim, Z.M. Preparation and characterization of activated carbon from oil palm empty fruit bunch wastes using zinc chloride. Jurnal Teknologi 2015, 74, 77-81, https://doi.org/10.11113/jt.v74.4876.

13. Herawan, S.G.; Hadi, M.S.; Ayob, M.R.; Putra, A. Characterization of activated carbons from oil-palm shell by $\mathrm{CO} 2$ activation with no holding carbonization temperature. The Scientific World Journal 2013, 2013, https://doi.org/10.1155/2013/624865.

14. Adinata, D.; Daud, W.M.A.W.; Aroua, M.K. Preparation and characterization of activated carbon from palm shell by chemical activation with $\mathrm{K}_{2} \mathrm{CO}_{3}$. Bioresource Technology 2007, 98, 145-149, https://doi.org/10.1016/j.biortech.2005.11.006.

15. Zhang, T.; Pan, Z.; Qian, C.; Chen, X. Isolation and purification of d-mannose from palm kernel. Carbohydrate Research 2009, 344, 1687-1689, https://doi.org/10.1016/j.carres.2009.06.018.

16. Kranjčec, B.; Papeš, D.; Altarac, S. D-mannose powder for prophylaxis of recurrent urinary tract infections in women: A randomized clinical trial. World Journal of Urology 2014, 32, 79-84, https://doi.org/10.1007/s00345-013-1091-6.

17. Zarei, M.; Ebrahimpour, A.; Hamid, A.A.; Anwar, F.; Saari, N. Production of defatted palm kernel cake protein hydrolysate as a valuable source of natural antioxidants. International Journal of Molecular Sciences 2012, 13, 8097-8111, https://doi.org/10.3390/ijms13078097.

18. Mba, O.I.; Dumont, M.J.; Ngadi, M. Palm oil: Processing, characterization and utilization in the food industry - A review. Food Bioscientific 2015, 10, 26-41, https://dx.doi.org/10.1016/j.fbio.2015.01.003.

19. Ahmad, A.L.; Chan, C.Y.; Shukor, S.R.A.; Mashitah, M.D.; Sunarti, A.R. Isolation of carotenes from palm oil mill effluent and its use as a source of carotenes. Desalination and Water Treatment 2009, 7, 251-256, https://doi.org/10.5004/dwt.2009.707.

20. Hassan, S.; Kee, L.S.; Al-Kayiem, H.H. Experimental study of palm oil mill effluent and oil palm frond waste mixture as an alternative biomass fuel. Journal of Engineering Science and Technology 2013, 8, 703712.

21. Rupani, P.F.; Signh, R.P.; Ibrahim, M.H.; Esa, N. Review of Current Palm Oil Mill Effluent (POME) Treatment Methods:Vermicomposting as a Sustainable Practice. World Applied Sciences Journal 2010, 10, 1190-1201,

22. Lee, Z.S.; Chin, S.Y.; Lim, J.W.; Witoon, T.; Cheng, C.K. Treatment technologies of palm oil mill effluent (POME)and olive mill wastewater (OMW): A brief review. Environment Technology \& Innovation 2019, 15, https://doi.org/10.1016/j.eti.2019.100377.

23. Hashim, K.; Tahiruddin, S.; Asis, A.J. Palm and Palm Kernel Oil Production and Processing in Malaysia and Indonesia. AOCS Press 2012, 2008, 235-250, http://dx.doi.org/10.1016/B978-0-9818936-9-3.50011-3.

24. Jagaba, A.H.; Kutty, S.R.M.; Hayder, G.; Latiff, A.A.A.; Aziz, N.A.A.; Umaru, I.; Ghaleb, A.A.S.; Abubakar, S.; Lawal, L.M.; Nasara, M.A. Sustainable use of natural and chemical coagulants for contaminants removal from palm oil mill effluent: A comparative analysis. Ain Shams Engineering Journal 2020, https://doi.org/10.1016/j.asej.2020.01.018.

25. Salihu, A.; Alam, Z. Palm oil mill effluent: A waste or a raw material? Journal of Applied Sciences Research 2012, 8, 466-473,.

26. Ahmad, A.L.; Chan, C.Y.; Shukor, S.R.A.; Mashitah, M.D. Recovery of oil and carotenes from palm oil mill effluent (POME). Chemical Engineerinf Journal 2008, 141, 383-386, https://doi.org/10.1016/j.cej.2008.03.00.

27. Gul, K. Tak, A.; Singh, A.K.; Singh, P.; Yousuf, B.; Wani, A.A. Chemistry, encapsulation, and health benefits of $\beta$-carotene-A review. Cogent Food and Agriculture 2015, 1, 1-12, https://doi.org/10.1080/23311932.2015.1018696.

28. Ciccone, M.M.; Cortese, F.; Gesualdo, M.; Carbonara, S.; Zito, A.; Ricci, G.; De Pascalis, F.; Scicchitano, P.; Riccioni, G. Dietary Intake of Carotenoids and Their Antioxidant and Anti-Inflammatory Effects in Cardiovascular Care. Mediators Inflammation 2013, 2013, https://doi.org/10.1155/2013/782137.

29. Dewanti, D.P. Potensi Selulosa dari Limbah Tandan Kosong Kelapa Sawit untuk Bahan Baku Bioplastik Ramah Lingkungan. Jurnal Teknologi Lingkungan 2018, 19, https://doi.org/10.29122/jtl.v19i1.2644.

30. Rosli, N.S.; Harum, S.; Jahim, J.M.; Othaman, R. Chemical and Physical Characterization of Oil Palm Empty. Malaysian Journal of Analytical Sciences 2017, 21, 188-196, http://dx.doi.org/10.17576/mjas-20172101-22.

31. Fahma, F.; Iwamoto, S.; Hori, N.; Iwata, T.; Takemura, A. Isolation, preparation, and characterization of nanoFibers from oil palm empty-fruit-bunch (OPEFB). Cellulose 2010, 17, 977-985, https://doi.org/10.1007/s10570-010-9436-4. 
32. Börjesson, M.; Westman, G. Crystalline Nanocellulose — Preparation, Modification, and Properties. Cellulose - Fundamental Aspects and Current Trends 2015, https://doi.org/10.5772/61899.

33. Firdausa, F.K.; Santoso, A.B.; Handayani, W. Ekstraksi Xilan dari Limbah Ampas Singkong dan Pemanfaatannya sebagai Substrat Endo-B-1,4-D-Xilanase. Berkala Sainstek 2017, 5, https://doi.org/10.19184/bst.v5i1.5376.

34. Hendriansyah, R.; Prakoso, T.; Widiatmoko, P.; Nurdin, I.; Devianto, H. Manufacturing Carbon Material by Carbonization of Cellulosic Palm Oil Waste for Supercapacitor Material. MATEC 2019, 156, https://doi.org/10.1051/matecconf/201815603018.

35. Shinoj, s.; Visvanathan, R.; Panigrahi, S.; Kochubabu, M. Oil palm Fiber (OPF) and its composites: A review. Industrial Crops and Products 2011, 33, 7-22, https://doi.org/10.1016/j.indcrop.2010.09.009.

36. Tsaniyah, J.E. Hermawan, H. Pengendalian Proses Produksi Bahan Pakan Bungkil Inti Sawit dalam Perspektif Keamanan Pangan. Jurnal OE, 2015, 7.

37. Ikumapayi, O.M.; Akinlabi, E.T. Composition, characteristics and socioeconomic benefits of palm kernel shell exploitation-an overview. Journal Environment Science Technology 2018, 11, 220-232, https://doi.org/10.3923/jest.2018.220.232.

38. Pasaribu, T. Efforts to Improve the Quality of Palm Kernel Cake through Fermentation Technology and Enzyme Addition for Poultry". Indonesian Bulletin of Animal and Veterinary Sciences 2018, 28, http://dx.doi.org/10.14334/wartazoa.v28i3.1820.

39. Sinurat, A.P.; Purwadaria, T.; Pasaribu, T. Peningkatan Nilai Gizi Bungkil Inti Sawit dengan Pengurangan Cangkang dan Penambahan Enzim. Jurnal Ilmu Ternak dan Veterier 2013, 18, 34-41.

40. Tafsin, M.; Hanafi, N.D.; Yusraini, E. Extraction process of palm kernel cake as a source of mannan for feed additive on poultry diet. Proceeding IOP Conference Series: Earth Environment Sciences, Indonesia 2017, 65, https://doi.org/10.1088/1755-1315/65/1/012020.

41. Tsouko, E.; Alexandri, M.; Fernandes, K.V.; Freire, D.M.G.; Mallouchos, A.; Koutinas, A.A. Extraction of phenolic compounds from palm oil processing residues and their application as antioxidants. Food Technology and Biotechnology 2019, 57, 29-38, https://doi.org/10.17113/ftb.57.01.19.5784.

42. Salleh, K.M.; Zakaria, S.; Sajab, M.S.; Gan, S.; Kaco, H. Superabsorbent hydrogel from oil palm empty fruit bunch cellulose and sodium carboxymethylcellulose. International Journal Biology and Macromolecular 2019, 131, 50-59, https://doi.org/10.1016/j.ijbiomac.2019.03.028.

43. Padzil, F.N.M.; Lee, S.H.; Ainun, Z.M.A.A.; Lee, C.H.; Abdullah, L.C. Potential of oil palm empty fruit bunch resources in nanocellulose hydrogel production for versatile applications: A review. Materials (Basel) 2020, 13, https://doi.org/10.3390/ma13051245.

44. Septevani, A.A.; Rifathin, A.; Sari, A.A.; Sampora, Y.; Ariani, G.N.; Sudiyarmanto.; Sondari, D. Oil palm empty fruit bunch-based nanocellulose as a super-adsorbent for water remediation. Carbohydrate Polymers 2020, 229, https://doi.org/10.1016/j.carbpol.2019.115433.

45. Daud, W. R. W.; Law, K. N. Oil palm Fibers as papermaking material: Potentials and challenges. BioResources 2011, 6, 901-917.

46. Famurewa J.A.V.; Olarewaja, A. Investigating The Potential of Dried Palm Oil Mill Effluents from Pressing and Water Displacement. Asian Journal of Natural and Applied Sciences 2013, 2, 58-68.

47. Teh, S.S.; Lau, H. L. N.; Mah, S. H. Palm-pressed mesocarp Fiber oil as an alternative carrier oil in emulsion. Journal Oleo Sciences 2019, 68, 803-808, https://doi.org/10.5650/jos.ess19098.

48. Lau, H.L.N.; Choo, Y.M.; Ma, A.N.; Chuah, C.H. Quality of residual oil from palm-pressed mesocarp Fiber (Elaeis guineensis) using supercritical $\mathrm{CO} 2$ with and without ethanol. Journal of American Oil Chemist Society 2006, 83, 893-898, https://doi.org/10.1007/s11746-006-5043-9.

49. Baby, R.; Saifullah, B.; Hussein, M.Z. Palm Kernel Shell as an effective adsorbent for the treatment of heavy metal contaminated water. Sciencitif Reports 2019, 9, 1-11, https://doi.org/10.1038/s41598-019-55099-6.

50. Rabiu, Z.; Hamzah, M.A.A.M.; Hasham, R.; Zakaria, Z.A. Characterization and anti-inflammatory properties of fractionated pyroligneous acid from palm kernel shell. Environmental Science and Pollution Research 2020, https://doi.org/10.1007/s11356-020-09209-x.

51. Rupani, P.F.; Embrandiri, A.; Ibrahim, M.H.; Ghole, V.; Lee, C.T.; Abbaspour, M. Effects of different vermicompost extracts of palm oil mill effluent and palm-pressed Fiber mixture on seed germination of mung bean and its relative toxicity. Environmental Science and Pollution Research 2018, 25, 35805-35810, https://doi.org/10.1007/s11356-018-1875-8.

52. Pujiasih, S.; Kurnia; Masykur, A.; Kusumaningsih, T.; Saputra, O.A. Silylation and characterization of microcrystalline cellulose isolated from indonesian native oil palm empty fruit bunch. Carbohydrate Polymers 2018, 184, 74-81, http://dx.doi.org/10.1016/j.carbpol.2017.12.060.

53. Yunus, R.; Salleh, S.F.; Abdullah, N.; Biak, D.R.A. Effect of ultrasonic pre-treatment on low temperature acid hydrolysis of oil palm empty fruit bunch. Bioresource Technology 2010, 101, 9792-9796, https://doi.org/10.1016/j.biortech.2010.07.074.

54. Elgharbawy, A.A.; Alam, M.Z.; Moniruzzaman, M.; Kabbashi, N.A.; Jamal, P. Chemical and structural changes of pretreated empty fruit bunch (EFB) in ionic liquid-cellulase compatible system for fermentability to bioethanol". 3 Biotechnology 2018, 8, https://doi.org/10.1007/s13205-018-1253-8. 
55. Neoh, B.K.;. Thang, Y.M.; Zain, M.Z. M.; Junaidi, A. Palm pressed Fiber oil: A new opportunity for premium hardstock? International Food Research Journal 2011, 18.

56. García, J.R.; Sedran, U.; Zaini, M.A.A.; Zakaria, Z.A.A. Preparation, characterization, and dye removal study of activated carbon prepared from palm kernel shell. Environment Science Pollutan Research 2018, 25, 5076-5085, https://doi.org/10.1007/s11356-017-8975-8.

57. Wang, P.; Zhang, J.; Shao, Q.; Wang, G. Physicochemical properties evolution of chars from palm kernel shell pyrolysis. Journal of Thermal Analysis and Calorimetry 2018, 133, 1271-1280, https://doi.org/10.1007/s10973-018-7185-z.

58. Ranta, K.; Nieminen, K.; Ekhoim, F.S.; Polavoka, M.; Roslund, M.U.; Salonranta, T.; Leino, R.; Savolainen, J. Evaluation of immunostimulatory activities of synthetic mannose-containing structures mimicking the $\beta$ $(1 \rightarrow 2)$-linked cell wall mannans of Candida albicans. Clinical and Vaccine Immunology 2012, 19, 18891893, https://doi.org/10.1128/CVI.00298-12.

59. Kamel, M.M.; Ali, H.I.; Anwar, M.M.; Mohamed, N.A.; Soliman, A.M.M. Synthesis, antitumor activity and molecular docking study of novel Sulfonamide-Schiff's bases, thiazolidinones, benzothiazinones and their C-nucleoside derivatives. European Journal of Medicinal Chemistry 2010, 45, 572-580, https://doi.org/10.1016/j.ejmech.2009.10.044.

60. Chen, F. E.; Zhao, J.F.; Xiong, F.J.; Xie, B.; Zhang, P. An improved synthesis of a key intermediate for (+)biotin from d-mannose. Carbohydrate Research 2007, 342, 2461-2464, https://doi.org/10.1016/j.carres.2007.06.029.

61. Mishra D. K.; Hwang, J.S. Selective hydrogenation of d-mannose to d-mannitol using NiO-modified TiO2 (NiO-TiO2) supported ruthenium catalyst. Applied Catalysis A General 2013, 453, 13-19, https://doi.org/10.1016/j.apcata.2012.11.042.

62. Ghoreishi S.M.; Shahrestani, R.G. Subcritical water extraction of mannitol from olive leaves. Journal Food Engineering 2009, 93, 474-481, https://doi.org/10.1016/j.jfoodeng.2009.02.015.

63. Chuanopparat, N.; Kongkathip, N.; Kongkathip. A new and efficient asymmetric synthesis of oseltamivir phosphate(Tamiflu) from D-mannose. Tetrahedron Letter 2012, 53, 6209-6211, https://doi.org/10.1016/j.tetlet.2012.08.143.

64. Hu, X.; Shi, Y.; Zhang, P.; Miao, M.; Zhang, T.; Jiang, B. d-Mannose: Properties, Production, and Applications: An Overview. Comprehensive Reviews Food Science and Food Safety 2016, 15, 773-785, https://doi.org/10.1111/1541-4337.12211.

65. Eshun, K.; He, Q. Aloe Vera: A Valuable Ingredient for the Food, Pharmaceutical and Cosmetic IndustriesA Review. Critical Reviews Food Science and Nutrition 2004, 44, 91-96, https://doi.org/10.1080/10408690490424694. 